\title{
Active axial spondyloarthritis: potential role of certolizumab pegol
}

This article was published in the following Dove Press journal:

Therapeutics and Clinical Risk Management

12 February 2014

Number of times this article has been viewed

\section{Sriya Ranatunga \\ Anne V Miller}

Department of Internal Medicine, Southern Illinois University School of Medicine, Springfield, IL, USA
Correspondence: Sriya Ranatunga Department of Internal Medicine, Southern Illinois University School of Medicine, Springfield, IL, USA

$\mathrm{Tel}+\mathrm{I} 2175450184$

$\mathrm{Fax}+\mathrm{I} 2175450540$

Email: sranatunga@siumed.edu
Abstract: The axial spondyloarthropathies are a group of chronic inflammatory diseases that predominantly affect the axial joints. This group includes ankylosing spondylitis and nonradiographic axial spondyloarthropathy. While the pathogenesis of axial spondyloarthropathies is not clear, immunologically active tissues primarily include the entheses, ie, the areas where ligaments, tendons, and joint capsules attach to bone and to the annulus fibrosis at the vertebrae. One of the major mediators of the immune response in this group of diseases is tumor necrosis factor-alpha (TNF $\alpha$ ). Blockade of TNF $\alpha$ results in reduced vascularity and inflammatory cell infiltration in the synovial tissues of affected joints. Certolizumab pegol (CZP) is an Fc-free, PEGylated anti-TNF $\alpha$ monoclonal antibody. CZP has unique properties that differ from other available TNF $\alpha$ inhibitors by virtue of its lack of an Fc region, which minimizes potential Fc-mediated effects, and its PEGylation, which improves drug pharmacokinetics and bioavailability. It has been shown in clinical trials that CZP improves patient outcomes and reduces inflammation in the sacroiliac joints and spine in both ankylosing spondylitis and nonradiographic axial spondyloarthropathies. These data support CZP as a treatment option for axial spondyloarthropathies.

Keywords: axial spondyloarthropathy, certolizumab pegol, anti-tumor necrosis factor-alpha, therapy

\section{Introduction}

The axial spondyloarthropathies (SpA) are a group of diseases characterized by inflammation at the axial joints, especially the sacroiliac joints. Other characteristic features are asymmetric oligoarthritis and enthesitis. Enthesitis, ie, inflammation of the insertional sites of ligaments, tendons, and joint capsules at the bone, is the pathologic feature that distinguishes these diseases from rheumatoid arthritis. ${ }^{1}$ Extra-articular features associated with axial $\mathrm{SpA}$ include genital and skin lesions, and eye and bowel inflammation. Some patients present with ongoing or preceding gastrointestinal or urinary tract infection. This group of diseases is strongly associated with the human leukocyte antigen (HLA)-B27.

The axial SpA are comprised of five subgroups with different extra-articular manifestations. These include ankylosing spondylitis, reactive arthritis, psoriatic arthritis, SpA associated with Crohn's disease and ulcerative colitis, and undifferentiated spondyloarthritis. The available evidence from immunopathologic analysis, structural changes, and response to treatment has not shown fundamental differences between the different SpA subtypes, suggesting that they share a common underlying pathophysiology. However, the data emerging from immunopathologic studies and 
clinical trials appear to show slight differences between axial and peripheral disease. This evidence favors disease classification into predominantly "axial" or "peripheral" SpA, rather than into subgroups defined by associated extra-articular disease manifestations. ${ }^{2} \mathrm{SpA}$ is further subdivided into ankylosing spondylitis and nonradiographic axial SpA. ${ }^{3}$

The prevalence of $\mathrm{SpA}$ is about $1 \%$, with ankylosing spondylitis being the most prevalent subtype, with an overall prevalence of about $0.5 \%{ }^{4,5}$ Prevalence varies among different populations and generally (but not perfectly) reflects the prevalence of HLA-B27. ${ }^{6}$

The natural course of the disease is that of progressive stiffness and bony ankylosis of the spine due to inflammation and new bone formation, leading to decreased mobility, functional impairment, and decreased quality of life. Disability occurs in up to $20 \%$ of patients with ankylosing spondylitis within 20 years of disease onset. ${ }^{7,8}$ Increased mortality has been observed in patients with ankylosing spondylitis due to spinal fractures, cervical subluxation, aortitis, atrioventricular conduction disorders, pulmonary fibrosis, and amyloidosis. Active disease and ongoing inflammation are significant risk factors for premature death in ankylosing spondylitis. Conversely, early detection and treatment of the disease can prevent premature death and functional disability in patients with ankylosing spondylitis. ${ }^{9}$ Nonsteroidal anti-inflammatory drugs (NSAIDs) are recommended as first-line therapy in addition to regular exercise and physical therapy. ${ }^{10,11}$ Biologic agents are recommended for patients with inadequate axial response to NSAIDs. In recent years, the US Food and Drug Administration (FDA) has approved several biological therapies for SpA, all being tumor necrosis factor-alpha (TNF $\alpha$ ) inhibitors. These include infliximab, adalimumab, etanercept, and golimumab. Certolizumab pegol (CZP), a recombinant humanized antibody Fab' fragment directed against TNF $\alpha$, has recently been granted FDA approval for the treatment of active ankylosing spondylitis and psoriatic arthritis. This article discusses the role of CZP in the treatment of SpA.

\section{Pathogenesis and mechanisms of inflammation in SpA Pathology of SpA}

The typical histologic finding of ankylosing spondylitis is that of multiple focal microscopic lesions in the tendons and ligaments at their attachment to bone, with associated erosion of the cortical bone. These lesions consist predominantly of lymphocytes and plasma cells, with some polymorphonuclear leucocytes. These inflammatory cells concentrate in the central part of the erosions and spread along the ligaments.
The marrow space adjacent to the lesions is edematous and lacks hematopoietic tissue. These areas are found at both peripheral and axial sites of involvement, including the peripheral tendinous insertions (enthesopathy), axial annulus-vertebral margins, sacroiliac joints, plantar fascia, and symphysis pubis. Healing erosions are characterized by deposition of reactive bone in a finely fibrous connective tissue without cartilage formation. Over time, healing of the inflammatory lesions in SpA leads to calcification and spur formation and, in the case of the axial spine, ankylosis. ${ }^{12}$

\section{Immunologic mechanisms in $\mathrm{SpA}$ and comparisons with rheumatoid arthritis}

The immunopathogenesis of SpA remains unclear. While there is a clear genetic predisposition, with the gene for HLA-B27 present in $>90 \%$ of patients with ankylosing spondylitis, the overall contribution of HLA-B27 to ankylosing spondylitis susceptibility is estimated to be only $30 \%$; its presence in other $\mathrm{SpA}$ is lower than in ankylosing spondylitis. Despite the increased risk that it confers, the presence of this gene is neither necessary nor sufficient to cause the disease, ${ }^{13}$ and its role continues to be debated. A long-promoted hypothesis in which an environmental trigger elicits a self-damaging inflammatory response in a genetically susceptible individual is strongly supported by observations of the immune activation in involved tissues and by clinical interventions that suppress components of the host inflammatory response. ${ }^{14}$ However, the exact nature of this immune response is unclear.

Analysis of the inflammatory synovitis associated with SpA reveals the cellular components characteristic of both innate and adaptive immunity, including $\mathrm{T}$ and B lymphocytes, dendritic cells, macrophages, natural killer cells, natural killer T cells, mast cells, and neutrophils. Focal bony lesions likewise contain $\mathrm{T}$ cells, B cells, and macrophages, and have been found to contain osteoclasts as well as cells involved in angiogenesis. ${ }^{15,16}$ These cells collaborate to generate high concentrations of inflammatory cytokines, primarily TNF $\alpha$ and interleukin-1 $\beta$, as well as histamine, vasoactive amines, and bradykinin. Local production of proteinase cathepsin $\mathrm{K}$ (thought to be produced by osteoclasts) and metalloproteinases (localizing to smaller mononuclear cells) has been described, and these are felt to play a role in formation of the observed erosions in SpA. ${ }^{17}$

Clinically, the presentations of SpA and rheumatoid arthritis differ in distribution of inflammatory involvement (annulus-vertebral/oligoarticular/enthesopathic versus polyarticular, respectively). Histologically, compared with 
rheumatoid arthritis, the synovial lining of peripheral joints with effusion in $\mathrm{SpA}$ are more vascular, and the vasculature is more tortuous. ${ }^{18}$ Although both develop bony erosions, those in SpA heal with new bone formation, while those of rheumatoid arthritis can progress to bony destruction. Descriptive studies of cellular markers show that, whereas highly specific markers for intracellular citrullinated proteins and human cartilage glycoprotein 39 peptides are often found in rheumatoid arthritis, they are absent in SpA. ${ }^{19}$ Synovial gene analysis has shown a highly disease-specific signature in SpA not found in rheumatoid arthritis, which was not altered by TNF blockade, suggesting that these patterns develop upstream in the disease process. ${ }^{20}$

Serologic and immunologic data suggest that SpA may be driven more by innate immune mechanisms than rheumatoid arthritis. An increase of CD163+ macrophages, neutrophils, interleukin-17-producing mast cells, and Toll-like receptors in $\mathrm{SpA}$, characteristic of innate immune activation, are not found in rheumatoid arthritis. ${ }^{21,22}$ The role of HLA-B27 in the pathogenesis of SpA and the role of the adaptive immune response in $\mathrm{SpA}$ is less evident, although it has been long recognized that serologically, autoantibody formation, a common feature of rheumatoid arthritis, is not a feature of SpA.

In summary, while our understanding of the immunopathologic features of the peripheral and axial spondyloarthropathies remains incomplete, they share similar immunopathologic mechanisms that appear to differ from those of rheumatoid arthritis. Both pathways of immune activation, however, lead to similar downstream effects in the form of inflammatory cytokines, in which TNF $\alpha$ appears to play a primary role.

\section{TNF $\alpha$ and its role in SpA}

TNF $\alpha$ is a $26 \mathrm{kDa}$ homotrimer that binds to one of two receptors (TNFR), ie, TNFRp55 or TNFRp75. Ligand binding leads to induction of signal transduction pathways that activate nuclear factor $\kappa \mathrm{B} .{ }^{23}$ Activated nuclear factor $\mathrm{\kappa B}$ enters the cell nucleus, inducing transcription of genes that code for proteins associated with a broad range of effector functions, including activation of inflammatory pathways and apoptosis.

Specific effects of TNF $\alpha$ in SpA include leukocyte activation, which leads to production of cytokines, endothelial cell activation leading to enhanced adhesion molecule expression, fibroblast activation leading to tissue matrix enzyme release and reduced collagen synthesis, enhanced leukocyte migration to the tissues, osteoclast activation, and elevation of acute phase reactants. ${ }^{14}$

\section{Diagnosis of axial SpA}

There is no universally accepted set of diagnostic criteria for SpA. The Modified New York criteria ${ }^{24}$ (Table 1) are the most widely used for diagnosis in the patient with radiographic changes of sacroiliitis. Patients in an early stage of the disease who do not fulfill the Modified New York criteria can be diagnosed by the Assessment of SpondyloArthritis International Society (ASAS) criteria $^{25}$ (Table 2).

\section{Management of SpA}

The therapeutic options for SpA include physical therapy, exercise, and patient education in combination with pharmacologic intervention.

\section{NSAIDS}

NSAIDs including cyclooxygenase (COX)-2 inhibitors are recommended as first-line pharmacologic treatment for SpA. These drugs are effective in relieving pain and stiffness. There is no proof of the superiority of one NSAID over another in ankylosing spondylitis, and there are no consistent differences between NSAIDs and COX-2 selective inhibitors. ${ }^{26}$ Adequate doses of at least two different NSAIDs should be tried for 4 weeks before concluding that response is inadequate ${ }^{25}$ and that other agents may be required. Studies of the effect of NSAIDs on radiographic progression have yielded conflicting results. ${ }^{26-29}$

\section{Glucocorticoids}

Oral glucocorticoids have limited efficacy in the treatment of axial SpA. Although both axial and peripheral joint pain and swelling may respond to short courses of glucocorticoids, long-term use is associated with side effects. Local glucocorticoid injections directed to the inflamed joints and entheses can provide temporary relief of symptoms. ${ }^{30,31}$

Table I Modified New York Criteria for Ankylosing Spondylitis

\section{Clinical criteria}

- Low back pain and stiffness which improves with activity for more than three months

- Limited range of motion of the lumbar spine in both forward and lateral bending.

- Limitation of chest expansion relative to normal values correlated for age and sex

\section{Radiological criteria}

- Sacroiliitis grade $\geq 2$ bilaterally

- Sacroiliitis grade 3 to 4 unilaterally

Note: Diagnosis of AS is made if the patient fulfills at least one radiological and one clinical criteria. Source: Copyright (c) 1984 American College of Rheumatology. van der Linden S, Valkenburg HA, Cats A. Evaluation of diagnostic criteria for ankylosing spondylitis. A proposal for modification of the New York criteria. Arthritis Rheum. 1984;27(4):36I-368..$^{24}$ 
Table 2 ASAS classification criteria for axial spondyloarthritis (SpA)

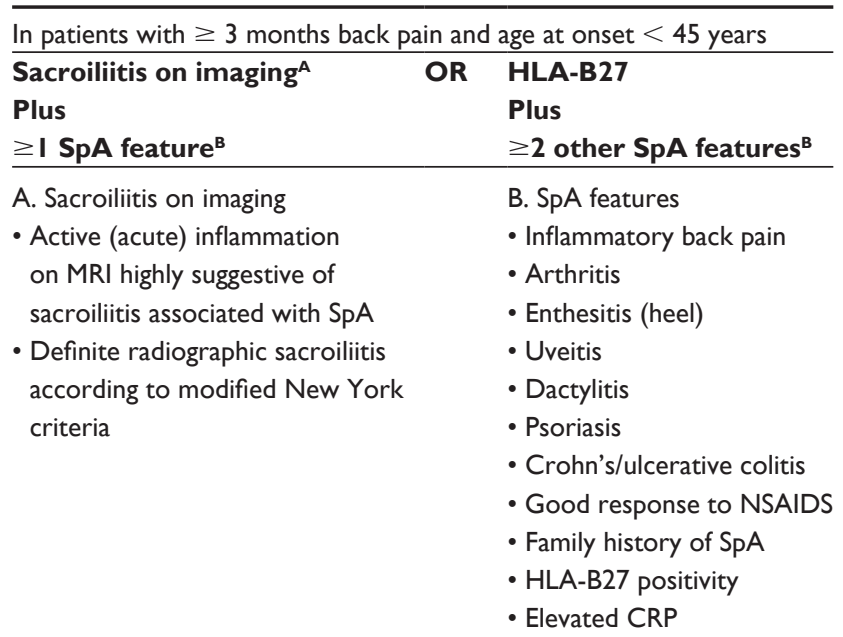

Notes: Reproduced from The development of Assessment of SpondyloArthritis international Society classification criteria for axial spondyloarthritis (part II): validation and final selection. Rudwaleit M, van der Heijde D, Landewe R, et al. Ann Rheum Dis. 68(6):777-783. Copyright @ 2009. With permission from BMJ Publishing Group. ${ }^{3}$

Abbreviations: ASAS, Assessment of SpondyloArthritis International Society; CRP, C-reactive protein; MRI, magnetic resonance imaging; NSAIDs, non-steroidal anti-inflammatory drugs. ${ }^{3}$

\section{Disease-modifying antirheumatic drugs}

The usual disease-modifying antirheumatic drugs, including sulfasalazine and methotrexate, have shown no efficacy in the treatment of axial disease. Sulfasalazine may be considered in patients with peripheral joint involvement. ${ }^{30,31}$

\section{TNF $\alpha$ blockers}

TNF $\alpha$-blocking agents have been shown to be effective in the treatment of SpA. They are effective in controlling axial skeletal pain, peripheral arthritis, enthesitis, morning stiffness, mobility, functional activities, pulmonary function, and overall quality of life. ${ }^{26}$ Combination therapy with conventional disease-modifying antirheumatic drugs has not demonstrated efficacy superior to that of monotherapy with anti-TNF. ${ }^{23} \mathrm{~A}$ meta-analysis of randomized clinical trials of the anti-TNF $\alpha$ agents infliximab, etanercept, adalimumab, and golimumab showed improvement of ASAS 20 response, disease activity, physical function, and vertebral mobility after treatment when compared with controls. ${ }^{32}$ Clinical trials have shown efficacy of anti-TNF $\alpha$ agents in inflammatory back pain classified as nonradiologic axial SpA in patients who had magnetic resonance imaging (MRI) findings of sacroiliitis, with partial remission rates of greater than $50 \%$. This response rate was better than that seen in patients with established ankylosing spondylitis. ${ }^{33}$

Efficacy is felt to be due to prevention of induction of TNFR-mediated cellular functions, including cell activation, cell proliferation, and cytokine and chemokine production. Long-term effects of anti-TNF $\alpha$ therapy include reduction of matrix-degrading enzymes and osteoclastogenic factors such as RANKL. ${ }^{34}$ Those anti-TNF agents that bind to transmembrane TNF can also induce apoptosis by complement-dependent cytotoxicity and antibody-dependent cellular cytotoxicity. The profound immune cascade blockade caused by anti-TNF $\alpha$ agents has been shown to result in downregulation of inflammation with subsequent tissue remodeling of the synovial membrane in SpA, with one study showing, after 12 weeks of treatment with infliximab, a reduction of synovial lining thickness, endothelial activation, and inflammatory cell infiltration with polymorphonuclear cells, macrophages, and T cells. ${ }^{35}$ Further evidence that improvement in these measures appears related to improvement in inflammation is suggested by reductions in inflammatory markers. ${ }^{36}$

While the inflammation of SpA has been known for years ${ }^{37-40}$ to be significantly decreased in patients treated with TNF $\alpha$ blockade, demonstration of similar reductions in radiographic progression and new bone formation has been more difficult, with shorter-term studies ${ }^{41-44}$ showing no benefit. Recent work has demonstrated that TNF inhibitors slow radiographic progression and new bone formation with prolonged and consistent use. They are most protective when started early in the disease and when use is constant and sustained over a long period of time. ${ }^{27}$

\section{Infliximab}

Infliximab is a chimeric monoclonal IgG1 antibody that binds to the soluble and cell-bound forms of TNF $\alpha$. It is administered at $5 \mathrm{mg} / \mathrm{kg}$ intravenously at baseline, week 2, and week 6 , followed by infusions every 6 weeks thereafter. The first randomized, double-blind, controlled trial of anti-TNF therapy demonstrating the efficacy of infliximab in ankylosing spondylitis was published in $2002,{ }^{36}$ and confirmed in the 24-week (and 3-year extended) Ankylosing Spondylitis Study for the Evaluation of Recombinant Infliximab Therapy (ASSERT) trial in 2004. ${ }^{45}$ Long-term efficacy was shown in disease activity and function in a study of 69 patients with active ankylosing spondylitis who were treated with infliximab $5 \mathrm{mg} / \mathrm{kg}$ every 6 weeks for 8 years, with almost $90 \%$ of patients achieving partial remission or low disease activity. ${ }^{46}$ FDA approval was granted in 2004.

\section{Etanercept}

Etanercept is a recombinant DNA-derived protein composed of TNFR linked to the Fc portion of human IgG1 fused to two extracellular domains of the TNFRp75. Etanercept binds the 
soluble form of TNF and blocks its interaction with cell surface receptors. Etanercept is administered in doses of $50 \mathrm{mg}$ subcutaneously per week or $25 \mathrm{mg}$ twice subcutaneously weekly. In a longitudinal study of patients with active axial and peripheral arthritis or enthesitis who had failed to respond to NSAIDs and traditional disease-modifying antirheumatic drugs, treatment with etanercept $25 \mathrm{mg}$ twice weekly achieved significant improvement of enthesitis and subchondral edema on MRI of the sacroiliac joints at 6 months. ${ }^{47}$ The effectiveness of etanercept was compared with that of sulfasalazine in two head-to-head randomized trials on patients with diagnoses of ankylosing spondylitis and nonradiographic axial SpA. Based on MRI findings, these trials showed definitive improvement of inflammation at the sacroiliac joints, spine, and enthesitic sites in patients treated with etanercept. Enthesitis detected by MRI was not improved in the sulfasalazine group. ${ }^{48,49}$

\section{Adalimumab}

Adalimumab is a recombinant monoclonal antibody that binds to human $\mathrm{TNF}^{50}$ at the $\mathrm{TNF} \alpha$ receptor sites, blocking the cytokine-driven inflammatory processes in SpA. It is approved by the FDA for use in ankylosing spondylitis at a dose of $40 \mathrm{mg}$ every other week, administered subcutaneously. Adalimumab has been shown in a randomized, placebo-controlled trial of patients with nonradiographic axial spondyloarthropathy to reduce disease activity, decrease inflammation, and improve quality of life after 12 weeks of treatment when administered at $40 \mathrm{mg}$ every 4 weeks. ${ }^{51}$ It has also been shown to reduce spinal and joint inflammation by MRI after 12 weeks of treatment, with efficacy maintained after 52 weeks of therapy. ${ }^{52}$

\section{Golimumab}

Golimumab is a fully human monoclonal antibody that binds to human $\mathrm{TNF} \alpha,{ }^{50}$ thereby interfering with endogenous TNF $\alpha$ activity. It may be administered with or without methotrexate or other nonbiologic disease-modifying antirheumatic drugs in psoriatic arthritis or ankylosing spondylitis. It has shown efficacy in ankylosing spondylitis after 24 weeks of treatment in a randomized, placebo-controlled trial. ${ }^{53}$ It is approved by the FDA for the treatment of ankylosing spondylitis and is administered at $50 \mathrm{mg}$ subcutaneously once monthly.

\section{Certolizumab pegol}

$\mathrm{CZP}$ is an Fc-free, PEGylated anti-TNF $\alpha$ monoclonal antibody that binds and neutralizes both soluble and transmembrane TNF $\alpha$ and inhibits signaling through both p55 and p75 TNFRs in vitro. ${ }^{54} \mathrm{CZP}$ differs from other TNF $\alpha$ inhibitors in its lack of an Fc region, which minimizes potential Fcmediated effects such as complement-dependent cytotoxicity. The lack of an Fc region may be a factor in prevention of the active transfer of CZP across the placenta during pregnancy. However, the clinical significance of this finding is currently unknown. Therefore, CZP is classified as pregnancy category B, as are the other four TNF inhibitors; this product should only be used during pregnancy if clearly needed. In contrast with other TNF inhibitors, CZP does not induce apoptosis in activated peripheral blood lymphocytes. Like infliximab and adalimumab (but not etanercept), it inhibits lipopolysaccharide-induced production of interleukin- $1 \beta .{ }^{55}$

CZP is able to offer the benefits of using only the Fab' fragment of monoclonal antibody by virtue of its PEGylation. In addition to reduction of antigenicity and immunogenicity, PEGylation improves the circulating half-life of a drug via reduction of its renal clearance (related to the increased size of the molecule). This increased circulatory half-life, which in the case of CZP is approximately 14 days for all doses administered, allows dosing intervals to be increased. ${ }^{56-58} \mathrm{CZP}$ has $80 \%$ bioavailability ${ }^{58}$ and has been shown to have increased permeability and persistence in inflamed tissues in mouse models when compared with adalimumab and infliximab; whether this is due to its PEGylation or lack of an Fc component is unclear. ${ }^{59}$ Despite having only a monovalent antibody fragment, unpublished data have suggested that CZP has a higher in vitro potency than divalent infliximab or adalimumab. ${ }^{60}$

\section{Immunogenicity of CZP}

Data from three studies involving patients with Crohn's disease has noted the development of antibodies directed against CZP in 6\%-12\% of patients receiving it. ${ }^{61-63}$ The presence of antibodies did not adversely affect response to therapy, even when associated with lower plasma concentrations of CZP; antibody levels were low in patients receiving concomitant immunosuppressant therapy. ${ }^{61}$

\section{CZP in clinical trials}

The demonstrated efficacy and safety of CZP in randomized clinical trials of patients with rheumatoid arthritis ${ }^{64-68}$ and Crohn's disease ${ }^{61,69}$ has resulted in FDA approval of its use in these diseases. CZP can be used as monotherapy or in combination with disease-modifying antirheumatic drugs for the treatment of moderate-to-severe rheumatoid arthritis. The recommended dose in rheumatoid arthritis is $400 \mathrm{mg}$ subcutaneously at weeks 0,2 , and 4 , and every 2 weeks thereafter. The dosing for Crohn's disease is $400 \mathrm{mg}$ subcutaneously at weeks $0,2,4$, followed by $400 \mathrm{mg}$ every 4 weeks. 
In the SpA spectrum of diseases, FDA approval has recently been granted for the use of CZP in ankylosing spondylitis and psoriatic arthritis. Approval for use in psoriatic arthritis in September 2013 was based on data from the RAPID-PsA study, an ongoing, multicenter, randomized, double-blind, placebo-controlled trial of 409 patients with psoriatic arthritis. CZP-treated patients demonstrated significant efficacy by week 12 , with improvements noted in arthritis, enthesitis, dactylitis, psoriasis, and physical function..$^{70}$ Approval for use in ankylosing spondylitis was granted in October 2013, based on a similar multicenter, randomized, double-blind, placebo-controlled trial involving 325 patients with ankylosing spondylitis that demonstrated significant efficacy by week $12 .^{71}$ In both of these trials, CZP dosed at $200 \mathrm{mg}$ every 2 weeks and $400 \mathrm{mg}$ every 4 weeks appeared to show similar efficacy. At this time, no studies are available showing CZP to have efficacy superior to that of other TNF $\alpha$ inhibitors available for the treatment of SpA.

\section{Conclusion}

Clinical trials available to date have shown subcutaneous CZP to be effective and to have an acceptable tolerability profile when used as monotherapy in active ankylosing spondylitis and nonradiographic axial SpA. Its structure as an Fc-free, PEGylated anti-TNF agent offers potentially unique benefits in the treatment of these debilitating disorders. Additional studies are needed to assess its long-term effects on disease activity and to further define its limitations and potential adverse effects in order to compare its profile with those of the other available anti-TNF $\alpha$ agents and thus determine its place in the SpA treatment armamentarium.

\section{Disclosure}

The authors certify that there is no conflict of interest with any financial organization regarding the material discussed in the manuscript.

\section{References}

1. Cawley MI, Chalmers TM, Kellgren JH, Ball J. Destructive lesions of vertebral bodies in ankylosing spondylitis. Ann Rheum Dis. 1972;31(5): 345-358.

2. Baeten D, Breban M, Lories R, Schett G, Sieper J. Are spondylarthritides related but distinct conditions or a single disease with a heterogeneous phenotype? Arthritis Rheum. 2013;65(1):12-20.

3. Rudwaleit M, van der Heijde D, Landewe R, et al. The development of Assessment of SpondyloArthritis international Society classification criteria for axial spondyloarthritis (part II): validation and final selection. Ann Rheum Dis. 2009;68(6):777-783.

4. Akkoc N, Khan M. Epidemiology of ankylosing spondylitis and related spondyloarthropathies. In: Weisman MH, Reveille JD, Van der Heijde D, editors. Ankylosing Spondylitis and the Spondyloarthropathies. Philadelphia, PA, USA: Mosby Elsevier; 2006.
5. Bakland G, Nossent HC, Gran JT. Incidence and prevalence of ankylosing spondylitis in Northern Norway. Arthritis Rheum. 2005;53(6): 850-855.

6. Khan MA. Epidemiology of HLA-B27 and arthritis. Clin Rheumatol. 1996;15 Suppl 1:10-12.

7. Ward MM. Quality of life in patients with ankylosing spondylitis. Rheum Dis Clin North Am. 1998;24(4):815-827.

8. Ward MM, Kuzis S. Risk factors for work disability in patients with ankylosing spondylitis. J Rheumatol. 2001;28(2):315-321.

9. Bakland G, Gran JT, Nossent JC. Increased mortality in ankylosing spondylitis is related to disease activity. Ann Rheum Dis. 2011;70(11): 1921-1925.

10. Dougados M, Dijkmans B, Khan M, Maksymowych W, van der Linden S, Brandt J. Conventional treatments for ankylosing spondylitis. Ann Rheum Dis. 2002;61 Suppl 3:iii40-iii50.

11. Kraag G, Stokes B, Groh J, Helewa A, Goldsmith C. The effects of comprehensive home physiotherapy and supervision on patients with ankylosing spondylitis - a randomized controlled trial. J Rheumatol. 1990;17(2):228-233.

12. Ball J. Enthesopathy of rheumatoid and ankylosing spondylitis. Ann Rheum Dis. 1971;30(3):213-223.

13. Braun J. Ankylosing spondylitis: pathology and pathogenesis. In: Klippel J, Stone J, Crofford L, White P, editors. Primer on the Rheumatic Diseases. 13th ed. New York, NY, USA: Springer; 2008.

14. FitzGerald O, McInnes I. Spondyloarthropathy: disease at the crossroads of immunity. Best Pract Res Clin Rheumatol. 2006;20(5): 949-967.

15. Appel H, Kuhne M, Spiekermann S, et al. Immunohistochemical analysis of hip arthritis in ankylosing spondylitis: evaluation of the bone-cartilage interface and subchondral bone marrow. Arthritis Rheum. 2006;54(6):1805-1813.

16. Francois RJ, Neure L, Sieper J, Braun J. Immunohistological examination of open sacroiliac biopsies of patients with ankylosing spondylitis: detection of tumour necrosis factor alpha in two patients with early disease and transforming growth factor beta in three more advanced cases. Ann Rheum Dis. 2006;65(6):713-720.

17. Neidhart M, Baraliakos X, Seemayer C, et al. Expression of cathepsin K and matrix metalloproteinase 1 indicate persistent osteodestructive activity in long-standing ankylosing spondylitis. Ann Rheum Dis. 2009;68(8):1334-1339.

18. Baeten D, Demetter P, Cuvelier C, et al. Comparative study of the synovial histology in rheumatoid arthritis, spondyloarthropathy, and osteoarthritis: influence of disease duration and activity. Ann Rheum Dis. 2000;59(12):945-953.

19. Baeten D, Kruithof E, De Rycke L, et al. Diagnostic classification of spondylarthropathy and rheumatoid arthritis by synovial histopathology: a prospective study in 154 consecutive patients. Arthritis Rheum. 2004;50(9):2931-2941.

20. Yeremenko N, Noordenbos T, Cantaert T, et al. Disease-specific and inflammation-independent stromal alterations in spondylarthritis synovitis. Arthritis Rheum. 2013;65(1):174-185.

21. Baeten D, Demetter P, Cuvelier CA, et al. Macrophages expressing the scavenger receptor CD163: a link between immune alterations of the gut and synovial inflammation in spondyloarthropathy. $J$ Pathol. 2002;196(3):343-350.

22. Noordenbos T, Yeremenko N, Gofita I, et al. Interleukin-17-positive mast cells contribute to synovial inflammation in spondylarthritis. Arthritis Rheum. 2012;64(1):99-109.

23. Chatzikyriakidou A, Georgiou I, Voulgari PV, Drosos AA. The role of tumor necrosis factor (TNF)-alpha and TNF receptor polymorphisms in susceptibility to ankylosing spondylitis. Clin Exp Rheumatol. 2009;27(4):645-648.

24. van der Linden S, Valkenburg HA, Cats A. Evaluation of diagnostic criteria for ankylosing spondylitis. A proposal for modification of the New York criteria. Arthritis Rheum. 1984;27(4):361-368. 
25. van der Heijde D, Sieper J, Maksymowych WP, et al. 2010 Update of the international ASAS recommendations for the use of anti-TNF agents in patients with axial spondyloarthritis. Ann Rheum Dis. 2011;70(6):905-908.

26. Toussirot E. Current therapeutics for spondyloarthritis. Expert Opin Pharmacother. 2011;12(16):2469-2477.

27. Haroon N, Inman RD, Learch TJ, et al. The impact of TNF-inhibitors on radiographic progression in ankylosing spondylitis. Arthritis Rheum. 2013; 65(10):2645-2654.

28. Kroon F, Landewe R, Dougados M, van der Heijde D. Continuous NSAID use reverts the effects of inflammation on radiographic progression in patients with ankylosing spondylitis. Ann Rheum Dis. 2012;71(10):1623-1629.

29. Song IH, Poddubnyy DA, Rudwaleit M, Sieper J. Benefits and risks of ankylosing spondylitis treatment with nonsteroidal antiinflammatory drugs. Arthritis Rheum. 2008;58(4):929-938.

30. Braun J, van den Berg R, Baraliakos X, et al. 2010 update of the ASAS/EULAR recommendations for the management of ankylosing spondylitis. Ann Rheum Dis. 2011;70(6):896-904

31. Lavie F, Pavy S, Dernis E, et al. Pharmacotherapy (excluding biotherapies) for ankylosing spondylitis: development of recommendations for clinical practice based on published evidence and expert opinion. Joint Bone Spine. 2007;74(4):346-352.

32. Machado MA, Barbosa MM, Almeida AM, et al. Treatment of ankylosing spondylitis with TNF blockers: a meta-analysis. Rheumatol Int. 2013;33(9):2199-2213.

33. Haibel H, Rudwaleit M, Listing J, et al. Efficacy of adalimumab in the treatment of axial spondylarthritis without radiographically defined sacroiliitis: results of a twelve-week randomized, double-blind, placebocontrolled trial followed by an open-label extension up to week fiftytwo. Arthritis Rheum. 2008;58(7):1981-1991.

34. Gengenbacher M, Sebald HJ, Villiger PM, Hofstetter W, Seitz M. Infliximab inhibits bone resorption by circulating osteoclast precursor cells in patients with rheumatoid arthritis and ankylosing spondylitis. Ann Rheum Dis. 2008;67(5):620-624.

35. KruithofE, Baeten D, Van den Bosch F, Mielants H, Veys EM, De Keyser F. Histological evidence that infliximab treatment leads to downregulation of inflammation and tissue remodelling of the synovial membrane in spondyloarthropathy. Ann Rheum Dis. 2005;64(4):529-536.

36. Braun J, Brandt J, Listing J, et al. Treatment of active ankylosing spondylitis with infliximab: a randomised controlled multicentre trial. Lancet. 2002;359(9313):1187-1193.

37. Revicki DA, Luo MP, Wordsworth P, Wong RL, Chen N, Davis JC Jr, et al, for the ATLAS Study Group. Adalimumab reduces pain, fatigue, and stiffness in patients with ankylosing spondylitis: results from the Adalimumab Trial Evaluating Long-Term Safety and Efficacy for Ankylosing Spondylitis (ATLAS) [published erratum appears in $\mathrm{J}$ Rheumatol 2011;38:788]. J Rheumatol 2008; 35:1346-53.

38. Van der Heijde D, Dijkmans B, Geusens P, Sieper J, DeWoody K, Williamson P, et al, and the Ankylosing Spondylitis Study for the Evaluation of Recombinant Infliximab Therapy Study Group. Efficacy and safety of infliximab in patients with ankylosing spondylitis: results of a andomized, placebo-controlled trial (ASSERT). Arthritis Rheum 2005;52:582-91.

39. Braun J, van der Horst-Bruinsma IE, Huang F, Burgos-Vargas R, Vlahos B, Koenig AS, et al. Clinical efficacy and safety of etanercept versus sulfasalazine in patients with ankylosing spondylitis: a randomized, double-blind trial. Arthritis Rheum 2011;63:1543-51.

40. Inman RD, Davis JC Jr, van der Heijde D, Diekman L, Sieper J, Kim SI, et al. Efficacy and safety of golimumab in patients with ankylosing spondylitis: results of a randomized, double-blind, placebo-controlled, phase III trial. Arthritis Rheum 2008; 58:3402-3412.

41. Van der Heijde D, Salonen D, Weissman BN, Landewe R, Maksymowych WP, Kupper H, et al, and the Canadian (M03-606) Study Group and the ATLAS Study Group. Assessment of radiographic progression in the spines of patients with ankylosing spondylitis treated with adalimumab for up to 2 years. Arthritis Res Ther 2009;11:R127.
42. Van der Heijde D, Landewe R, Baraliakos X, Houben H, van Tubergen A, Williamson P, et al, and the Ankylosing Spondylitis Study for the Evaluation of Recombinant Infliximab Therapy Study Group. Radiographic findings following two years of infliximab therapy in patients with ankylosing spondylitis. Arthritis Rheum 2008;58:3063-70.

43. Van der Heijde D, Landewe R, Einstein S, Ory P, Vosse D, Ni L, et al. Radiographic progression of ankylosing spondylitis after up to two years of treatment with etanercept. Arthritis Rheum. 2008;58:1324-31.

44. Gran JT, Skomsvoll JF. The outcome of ankylosing spondylitis: a study of 100 patients. Br J Rheumatol. 1997;36:766-771.

45. van der Heijde D, Dijkmans B, Geusens P, et al. Efficacy and safety of infliximab in patients with ankylosing spondylitis: results of a randomized, placebo-controlled trial (ASSERT). Arthritis Rheum. 2005;52(2):582-591.

46. Baraliakos X, Listing J, Fritz C, et al. Persistent clinical efficacy and safety of infliximab in ankylosing spondylitis after 8 years - early clinical response predicts long-term outcome. Rheumatology (Oxford). 2011;50(9):1690-1699.

47. Marzo-Ortega H, McGonagle D, O'Connor P, Emery P. Efficacy of etanercept in the treatment of the entheseal pathology in resistant spondylarthropathy: a clinical and magnetic resonance imaging study. Arthritis Rheum. 2001;44(9):2112-2117.

48. Braun J, van der Horst-Bruinsma IE, Huang F, et al. Clinical efficacy and safety of etanercept versus sulfasalazine in patients with ankylosing spondylitis: a randomized, double-blind trial. Arthritis Rheum. 2011;63(6):1543-1551.

49. Song IH, Hermann K, Haibel H, et al. Effects of etanercept versus sulfasalazine in early axial spondyloarthritis on active inflammatory lesions as detected by whole-body MRI (ESTHER): a 48-week randomised controlled trial. Ann Rheum Dis. 2011;70(4):590-596.

50. Nash PT, Florin TH. Tumour necrosis factor inhibitors. Med J Aust. 2005;183(4):205-208

51. Sieper J, van der Heijde D, Dougados M, et al. Efficacy and safety of adalimumab in patients with non-radiographic axial spondyloarthritis: results of a randomised placebo-controlled trial (ABILITY-1). Ann Rheum Dis. 2013;72(6):815-822.

52. Lambert RG, Salonen D, Rahman P, et al. Adalimumab significantly reduces both spinal and sacroiliac joint inflammation in patients with ankylosing spondylitis: a multicenter, randomized, doubleblind, placebo-controlled study. Arthritis Rheum. 2007;56(12): 4005-4014.

53. Inman RD, Davis JC Jr, Heijde D, et al. Efficacy and safety of golimumab in patients with ankylosing spondylitis: results of a randomized, double-blind, placebo-controlled, phase III trial. Arthritis Rheum. 2008;58(11):3402-3412.

54. Deeks ED. Certolizumab pegol: a review of its use in the management of rheumatoid arthritis. Drugs. 2013;73(1):75-97.

55. Nesbitt A, Fossati G, Bergin M, et al. Mechanism of action of certolizumab pegol (CDP870): in vitro comparison with other anti-tumor necrosis factor alpha agents. Inflamm Bowel Dis. 2007;13(11):1323-1332.

56. Veronese FM, Pasut G. PEGylation, successful approach to drug delivery. Drug Discov Today. 2005;10(21):1451-1458.

57. Chapman AP. PEGylated antibodies and antibody fragments for improved therapy: a review. Adv Drug Deliv Rev. 2002;54(4):531-545.

58. US Food and Drug Administration. UCBPharma. Cimzia (certolizumab pegol) lyophilized powder or solution for subcutaneous use: US prescribing information. 2012. Available from; http://www.accessdata. fda.gov/drugsatfda_docs/label/2012/125160s189lbl.pdf. Accessed November 12, 2013

59. Palframan R, Airey M, Moore A, Vugler A, Nesbitt A. Use of biofluorescence imaging to compare the distribution of certolizumab pegol, adalimumab, and infliximab in the inflamed paws of mice with collageninduced arthritis. J Immunol Methods. 2009;348(1-2):36-41.

60. Nesbitt A, Henry A. High affinity and potency of the pegylated Fab' fragment CDP870. Direct comparison with other anti-TNF agents. Am J Gastroenterol. 2004;99 Suppl 10:S253. 
61. Schreiber S, Khaliq-Kareemi M, Lawrance IC, et al. Maintenance therapy with certolizumab pegol for Crohn's disease. $N$ Engl J Med. 2007;357(3):239-250

62. Schreiber S, Rutgeerts P, Fedorak RN, et al. A randomized, placebocontrolled trial of certolizumab pegol (CDP870) for treatment of Crohn's disease. Gastroenterology. 2005;129(3):807-818.

63. Sandborn WJ, Abreu MT, D'Haens G, et al. Certolizumab pegol in patients with moderate to severe Crohn's disease and secondary failure to infliximab. Clin Gastroenterol Hepatol. 2010;8(8): 688-695. e682.

64. Smolen J, Landewe RB, Mease P, et al. Efficacy and safety of certolizumab pegol plus methotrexate in active rheumatoid arthritis: the RAPID 2 study. A randomised controlled trial. Ann Rheum Dis. 2009;68(6):797-804.

65. Fleischmann R, Vencovsky J, van Vollenhoven RF, et al. Efficacy and safety of certolizumab pegol monotherapy every 4 weeks in patients with rheumatoid arthritis failing previous disease-modifying antirheumatic therapy: the FAST4WARD study. Ann Rheum Dis. 2009;68(6): 805-811.

66. Keystone E, Heijde D, Mason D Jr, et al. Certolizumab pegol plus methotrexate is significantly more effective than placebo plus methotrexate in active rheumatoid arthritis: findings of a fifty-two-week, phase III, multicenter, randomized, double-blind, placebo-controlled, parallel-group study. Arthritis Rheum. 2008;58(11):3319-3329.
67. Choy EH, Hazleman B, Smith M, et al. Efficacy of a novel PEGylated humanized anti-TNF fragment (CDP870) in patients with rheumatoid arthritis: a phase II double-blinded, randomized, dose-escalating trial. Rheumatology (Oxford). 2002;41(10):1133-1137.

68. Ruiz Garcia V, Jobanputra P, Burls A, et al. Certolizumab pegol (CDP870) for rheumatoid arthritis in adults. Cochrane Database Syst Rev. 2011;2:CD007649

69. Sandborn WJ, Feagan BG, Stoinov S, et al. Certolizumab pegol for the treatment of Crohn's disease. N Engl J Med. 2007;357(3):228-238.

70. Mease PJ, Fleischmann R, Deodhar AA, et al. Effect of certolizumab pegol on signs and symptoms in patients with psoriatic arthritis: 24-week results of a Phase 3 double-blind randomised placebo-controlled study (RAPIDPsA). Ann Rheum Dis. October 16, 2013. [Epub ahead of print.]

71. Landewe R, Braun J, Deodhar A, et al. Efficacy of certolizumab pegol on signs and symptoms of axial spondyloarthritis including ankylosing spondylitis: 24-week results of a double-blind randomised placebocontrolled Phase 3 study. Ann Rheum Dis. September 6, 2013. [Epub ahead of print.]
Therapeutics and Clinical Risk Management

\section{Publish your work in this journal}

Therapeutics and Clinical Risk Management is an international, peerreviewed journal of clinical therapeutics and risk management, focusing on concise rapid reporting of clinical studies in all therapeutic areas, outcomes, safety, and programs for the effective, safe, and sustained use of medicines. This journal is indexed on PubMed Central, CAS,

\section{Dovepress}

EMBase, Scopus and the Elsevier Bibliographic databases. The manuscript management system is completely online and includes a very quick and fair peer-review system, which is all easy to use. Visit http://www.dovepress.com/testimonials.php to read real quotes from published authors.

Submit your manuscript here: http://www.dovepress.com/therapeutics-and-clinical-risk-management-journal 